striking leadership and brilliance of success or failure, revealed -courage, constancy, loyalty, unselfishness, ideality. That type of leader in Iowa usually failed in the sense of personal pecuniary fortune, but his visions usually became verities which our own generation has realized upon without much risk or effort. As W. A. Scott is a figure in the story of the location of the capital at Des Moines, so is his prototype conspicuous in the erection of almost every early public structure, daring line of transportation, and of more than one educational and religious institution.

The Historical Department is committed with the Polk County Pioneer Association to the proposition of placing a monument mass befitting his name and place over the bones of this most striking figure of that picturesque group of building pioneers.

\title{
IOWA'S YOUNGEST BRIGADIER GENERAL
}

Our friend J. D. Edmundson of Des Moines calls our attention to an inaccurate statement in the Anvals of July, 1921, where in speaking of Samuel L. Glasgow, we say he "was the youngest of his rank from Iowa," the rank being brevet brigadier-general. On examining the "Roster of Iowa Soldiers in War of the Rebellion," and the "Historical Register of the United States Army," and other authorities we find these interesting facts: Francis J. Herron was born February 17, 1837, and on July 30,1862 , he was promoted to brigadier-general, his age then being twenty-five years, five months, and thirteen days. Samuel L. Glasgow was born September 17, 1838, and on December 19, 1864, was breveted brigadier-general, his age then being twenty-six years, three months, and two days. Thus General Herron at the time he was made a general was over nine months younger than was General Glasgow when he was breveted brigadier-general, and the honors seem to be with General Herron. However, Glasgow was a younger man than Herron by one year and seven months, so that when Glasgow received his promotion in December, 1864, it could be said of him that "he was the youngest of his rank from Iowa" at that time, although not the youngest brigadier-general from Iowa at any time. It seemed like almost an even race between these two gallant officers for that honor. 
Copyright of Annals of Iowa is the property of State of Iowa, by \& through the State Historical Society of Iowa and its content may not be copied or emailed to multiple sites or posted to a listserv without the copyright holder's express written permission. However, users may print, download, or email articles for individual use. 